\title{
Kultur Büro Elisabeth w Berlinie - kościoły do wynajęcia
}

\author{
Marta Alina Rusnak \\ Katedra Historii Architektury, Sztuki i Techniki, \\ PolitechnikaWroctawska,marta.rusnak@pwr.edu.pl
}

Streszczenie: Po II Wojnie Światowej w Berlinie, tak jak w całych Niemczech i Europie, postępowało zjawisko laicyzacji społeczeństwa. W wielu miejscach skala zeświecczenia skutkowała koniecznością poszukiwania nie tylko rozwiązań w celu ratowania kurczących się budżetów wspólnot religijnych, ale także sposobów na pożyteczne i atrakcyjne ożywienie coraz rzadziej wykorzystywanych obiektów będących w posiadaniu Kościoła. Opuszczone świątynie oznaczały również fragmentaryczną utratę spójności miasta, częściowo utracone zostały bowiem niegdyś istotne związki społeczne podtrzymywane przez spotkania religijne. W Berlinie, a w szczególności w dzielnicy Mitte, problem ekonomicznej eksploatacji przestrzeni religijnych stopniowo zyskiwał na znaczeniu, a pomysły na rozwiązanie sytuacji ewoluowały przez niemal 50 lat. W wyniku stopniowych transformacji powstało Kultur Büro Elisabeth. Organizację powołano, aby ocalić światowej klasy zabytek architektury, autorstwa K.F. Schinkla, a także, by odtworzyć dawne relacje przestrzenne i społeczne. W efekcie prowadzonego przez wiele lat dialogu stworzono także warunki do wieloaspektowej rewitalizacji wszystkich ewangelickich obiektów religijnych w tej części miasta oraz kreowania współczesnych wartości kulturowych dzięki, którym wskrzeszane lub reinterpretowane są ich cechy. Co istotne, organizacja od 2014 roku funkcjonuje bez dotacji - oznacza to, że wypracowano tam model postępowania, który jest satysfakcjonujący także pod względem ekonomicznym. $Z$ tego powodu należałoby dobrze poznać ten mechanizm i zastanowić się nad możliwością jego adaptacji na gruncie Polskim.

Słowa kluczowe: kościoły, rewitalizacja, kulturowa adaptacja, ruina, zarządzanie zabytkami, Berlin.

\section{Wstęp. Synergia w ochronie zabytku}

W poniższej pracy opisano, czym może być efekt synergii w ochronie i adaptacji zabytku sakralnego. Aby zakwalifikować jakiś proces adaptacji jako synergetyczny należy zbadać, czy energia poświęcona na jego zachowanie obiektu zaowocowała dodatkowymi korzyściami, przekraczającymi sumę włożonego wysiłku oraz funduszy [1] $]^{1}$ W ochronie zabytku korzyści te nie muszą być rozumiane w sposób dosłowny, jako poprawa stanu obiektu lub korzyść ekonomiczna związana z obniżeniem kosztów eksploatacji. Profity można definiować także jako zachowanie dziedzictwa niematerialnego: wspieranie działań prospołecznych, kulturowych lub utrzymanie praktyk religijnych.

Tych pozamaterialnych dóbr zwykle nie da się wycenić. Z pewną namiastką ich mierzalności możemy mieć jednak do czynienia w opisanym poniżej przypadku Kultur Büro Elisabeth w Berlinie, tam bowiem z zabytkowej niepowtarzalności obiektów sakralnych uczyniono wartość rynkową. W czasie trwającej od lat 90 . XX wieku rewitalizacji synchronizowano ze sobą interwencję architektoniczno-budowlaną, działania prospołeczne oraz

\footnotetext{
${ }^{1}$ synergizm - współdziałanie różnych czynników, skuteczniejsze niż suma ich oddzielnych działań.
} 
marketingowe. W wyniku wypracowanej przez niemal 10 lat (1998-2007) formuły, pieniądze pozyskane z działalności komercyjnej są obecnie w całości przeznaczane na utrzymanie kościołów, wspieranie debiutujących artystów i szeroko rozumiane intelektualne pobudzanie mieszkańców tej części Berlina, a obecnie Kultur Büro Elisabeth funkcjonuje na zasadach non profit, nie wymaga więc żadnego wsparcia od władz świeckich czy kościelnych.

To co z perspektywy badawczej jest interesujące to opisanie procesu i warunków tej transformacji oraz wydobycie tych cech, które pozwoliły na osiągniecie sukcesu.

\section{Laicyzacja berlińskiego społeczeństwa a problematyka utrzymania zabytkowych kościołów}

Po II Wojnie Światowej w Berlinie, tak jak w całych Niemczech i Europie, postępowało i postępuje zjawisko laicyzacji społeczeństwa ${ }^{2}[2,3]$. W efekcie dawne zasady użytkowania przestrzeni publicznych ewoluowały. W wielu miejscach w Niemczech skala zeświecczenia byłą tak duża, że szybko skutkowała koniecznością poszukiwania nie tylko ratunku dla kurczących się budżetów wspólnot religijnych, ale także sposobów pożytecznego i atrakcyjnego ożywienia coraz rzadziej wykorzystywanych obiektów będących w posiadaniu Kościoła. Dodatkowo sytuację niektórych wspólnot religijnych komplikowała konieczność odnalezienia odpowiedzi na pytanie, w jaki sposób odnieść się do tych zabytków architektury sakralnej, które w wyniku zaniedbań, zamachów lub działań wojennych znalazły się w stanie ruiny.

\subsection{Krótko o historii miejsca}

Aby w pełni zrozumieć opisywany proces pozwolę sobie na zarysowanie dziejów i historycznych relacji rewitalizowanych później obiektów sakralnych. Jak się wydaje jest to niezbędne, aby w pełni zrozumieć znaczenie, zakres i pełną logikę tych działań.

Najstarszym z sześciu omawianych, obecnie aktywizowanych przestrzeni poreligijnych jest kościół Sophienkirche (rys. 1) wzniesiony w latach 1680-1711, za sprawą królowej Sophie Charlotte $[4]^{3}$. Sophienkirche stał się zarodkiem i punktem centralnym ewangelickiej wspólnoty zamieszkującej przedmieście Spandau. W związku z tą prospołeczną rolą ówczesne władze zdecydowały się przebudować okolice kościoła, urządzając tam niewielki skwer. Miało to wspierać integrację coraz liczniejszych wiernych, dając im estetyczną przestrzeń spotkań, zabaw i spacerów. Tak rozpoczęła się tradycja uwypuklania oddziaływania ewangelickiej duchowości w przestrzeni urbanistycznej przedmieścia. Dominująca rola tego miejsca utrzymywała się do lat 40. XIX w., gdy centrum życia religijnego zaczął pełnić nowy kościół.

Potrzebę wzniesienia kolejnej świątyni zauważono już w 1827 r. Nowy kościół - Elisabethkirche - był jedną z czterech świątyń, mających zaspokoić religijne potrzeby mieszkańców osiedlających się w obrębie dynamicznie rozwijającego się Berlina $[5,6,7]^{4}$. Fundatorem budowy tych kościołów był król Fryderyk Wilhelm III. Prace projektowe zostały

\footnotetext{
${ }^{2}$ W Berlinie o zaawansowaniu tego procesu świadczy chociażby liczba obywateli, którzy płacą podatek kościelny. 30\% wskaźnik stanowi wielkość dwukrotnie mniejszą niż średnia policzona dla całych Niemiec. Patrz [1]. Współczynnik ekonomiczny nie jest w pełni miarodajny (podatków przecież można unikać), ale daje pewne wyobrażenie o coraz bardziej marginalnej roli, jaką w stolicy Niemiec odgrywają praktykujący chrześcijanie.

3 Kościół był wielokrotnie przebudowywany po raz pierwszy w 1830 r. Drugą dużą interwencje połączoną z wymianą dachu przeprowadzono w latach 1891-1892.

${ }^{4}$ Oprócz wspomnianego Elisabthkirche mowa tu o Nazarethkirche, Paulskirche oraz Johanniskirche.
} 
zlecone znanemu już wtedy Karlowi Friedrichowi Schinklowi, który stworzył kilka koncepcji. Ostatecznie król w 1830 r. jako lokalizację kościoła dla Spandau wybrał obecną Invalidenstrasse i skierował do realizacji wariant o antykizującej stylistyce, zakończony absydą, z drewnianym wyposażeniem pomyślanym dla 1200 osób [8,9]. Budowa trwała dwa lata, od 1832 do 1834, choć oficjalne otwarcie nastąpiło dopiero 28 czerwca 1835 r. Kościół uznano za udany, choć prędko zauważono funkcjonalne niedociągnięcia. Stąd w latach 1859-60 przebudowie uległa część prezbiterialna, do której dostawiono dwie zakrystie. Wprowadzenia zmian podjął się uczeń K.F. Schinkla, Gottfried August Stüler ${ }^{5}$.

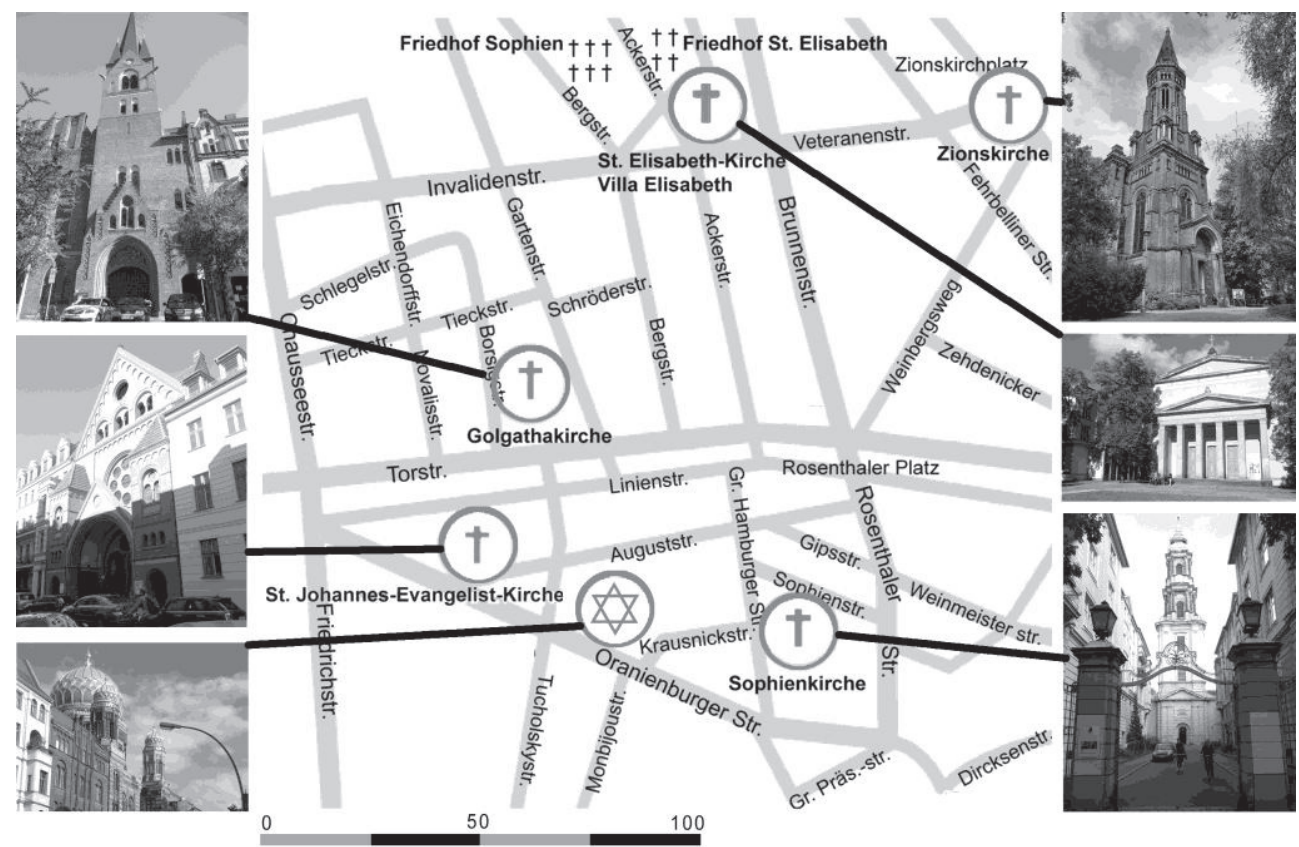

Rys. 1. Lokalizacje obiektów religijnych lub poreligijnych wraz z ich wizerunkami. (fot. Marta Rusnak)

Kolejnym obiektem służącym tamtejszej wspólnocie ewangelickiej był Zionskirche (rys. 1), wzniesiony w 1873 r. w manierze Rundbogenstilu według projektu Augusta Orta, również noszącego miano architekta królewskiego. Autor zafascynowany był twórczością K.F. Schinkla i chciał wpisać się w ideę Vorstadtkirche, czyli czterech świątyń ufundowzanych przez Fryderyka Wilhelma III [10].

Dwa wzniesione jako ostatnie na przedmieściu Spandau kościoły łączy osoba projektanta, Maxa Spitty, oraz nietypowe i mało reprezentacyjne działki pierwotnie przeznaczone pod zabudowę mieszkaniową. Oba neogotyckie budynki, St. Johannes-Evagelist-Kirche (rys. 1) i Golgathakirche (rys. 1), wybudowano w latach 1898-1901 [11], a współtwórcą tego drugiego był Karl Wilde [12,13].

W latach 1905-1907 kompleks religijny wspólnoty Spandau wzbogacono o przylegający do kościoła St. Elisabeth budynek tzw. willi biskupów (rys. 1). Był to nie tylko budynek mieszkalny. Organizowano w nim przede wszystkim zgromadzenia, szkolenia, akademie, obchodzono tam różnego rodzaju uroczystości religijne i państwowe. Stąd w planie budynku odnajdziemy kilka rozległych sal oraz dwupoziomową aulę o secesyjnej dekoracji.

\footnotetext{
${ }^{5}$ Autor Neue Museum w Berlinie oraz współautor wspominanego w artykule projektu Neue Synagogue.
} 
W budynku zastosowano kilka innowacyjnych rozwiązań miedzy innymi opuszczaną ścianę, umożliwiającą dostosowanie liczby i wielkości pomieszczeń do bieżących potrzeb funkcjonalnych. Ta inwestycja ostatecznie przechyliła szalę, pokazując dominującą rolę kościoła St. Elisabeth i tej lokalizacji oraz dążenie do uwspółcześnionego rozwijania znaczenia wspólnoty.

Przedstawione powyżej miejsca kultu na przedmieściu Spandau - Elisabethkirche, Sophienkirche, Zionskirche, Goglathakirche oraz St. Johannes-Evangelist-Kirche - od początku XX wieku były nazywane siostrzanymi, co miało również odzwierciedlenie w dobrych relacjach pięciu parafii. O społecznej roli tych obiektów w kształtowaniu spójności struktury miasta może świadczyć plakat z 1935 r. (rys. 2) [14,15], a także wzniesione z funduszy tych parafii szpital z kaplicą ${ }^{6}$, szkoła podstawowa i dwukrotnie rozbudowywana kapituła. Afisz powstał przy okazji 100 rocznicy budowy St. Elisabeth. Sam kościół, jako obiekt o znaczeniu lokalnym, ale także jako pomnik historii narodu, przeszedł gruntowną renowację. Prace konserwatorskie opisano w specjalnie na tę okazję przygotowanej publikacji [16] wpisującej się w istotny z punktu widzenia totalitarnej władzy nurt budowania dumy narodowej.

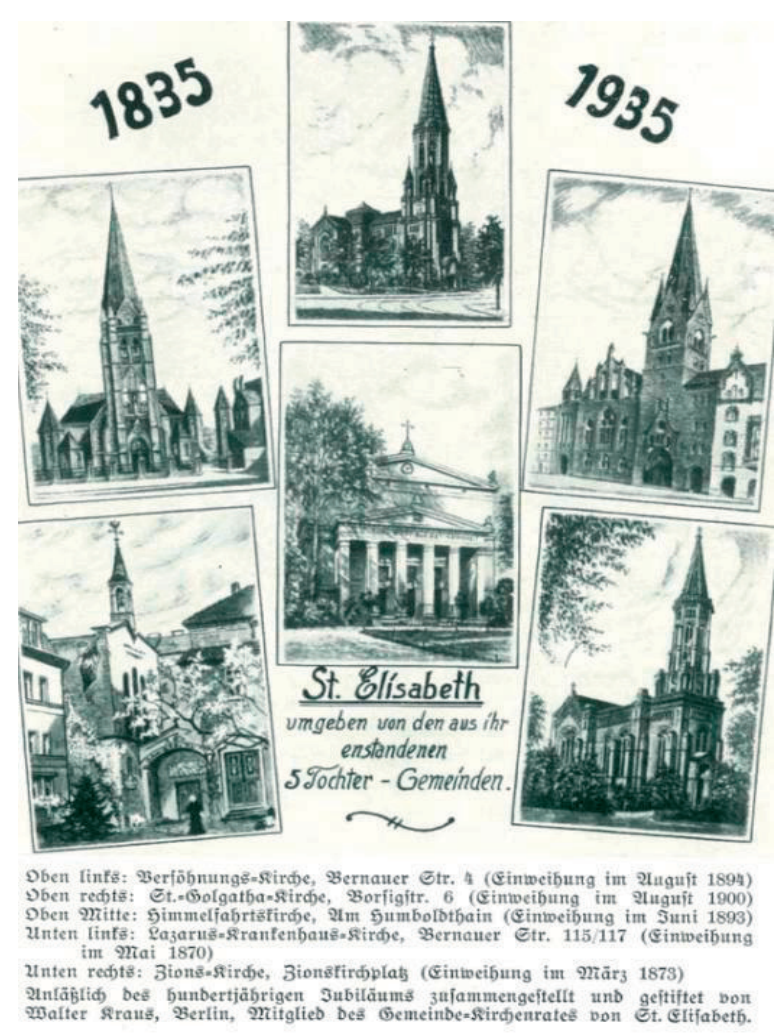

Rys. 2. Afisz przygotowany z okazji 100-lecia kościoła St.Elisabeth pokazujący obiekty religijne pięciu siostrzanych parafii (Kultur Büro Elisabeth)

Na skutek bombardowań na przełomie kwietnia i maja 1945 r., kościół St. Elisabeth spłonął. Pożar strawił całe zabytkowe wnętrze. W wyniku zniszczenia więźby dachowej

\footnotetext{
${ }^{6}$ Przykościelna kaplica pokazana jest również na plakacie (rys. 2).
} 
oraz zerwania się empor uszkodzeniu uległy mury obwodowe, w których zakotwione były drewniane konstrukcje. W rezultacie tych samych zdarzeń uszkodzone zostały także pozostałe kościoły. Bomby nadszarpnęły większość więźb dachowych i okien. W dwóch kościołach przebiciu uległy spore fragmenty sklepień, a na ścianach obwodowych pojawiły się spękania. Duża część wyposażenia wnętrz została następnie rozkradziona. Smutnego obrazu dopełniały zgliszcza synagogi przy Oranienburger Straße, która została zniszczona jeszcze przed wybuchem II Wojny Światowej w czasie słynnej nocy kryształowej (rys. 3) $[17,18]$. Po zakończeniu działań wojennych mieszkańcy przedmieścia musieli przy ograniczonych środkach podjąć decyzję o chronologii działań naprawczych licznych obiektów o religijnej tożsamości. Za logiczne uznano wykonanie prac zabezpieczających przed dalszą destrukcją. Usuwano usterki w budynkach mniej zniszczonych, odsuwając problem obydwu ruin na późniejsze lata. Początkowy brak spektakularnych posunięć nie dziwi, gdyż powojenna ,skala zniszczeń była tak ogromna ze nawet bogate Niemcy Zachodnie nie były w stanie rekonstruować wszystkich obiektów zabytkowych, nawet jeżeli posiadano dokumentację i ikonografię tej czy innej budowli” [19]. Nie można było oczywiście oczekiwać większej aktywności w obrębie Niemiec Wschodnich, gdzie trudności nie były wyłącznie natury finansowej, ale także polityczno-społecznej. Problem stanowiła wreszcie sama wojenna trauma, konflikt bowiem poczynił nie tylko zniszczenia fizyczne, ale przyczynił się także do destrukcji pojęć i relacji pomiędzy znaczeniami. Społeczeństwo Niemieckie potrzebowało czasu na przetrawienie tego trudnego doświadczenia, jakim było chociażby częste wykorzystywanie religii jako elementu uwiarygodniającego szerzoną propagandę $[20]^{7}$. Pamięć historyczna, a tym samym zabytki architektury, stały się polem zmagań, w wyniku którego formułowano nowe rozumienie tożsamości narodowej [21,22].

Niewątpliwie pozytywną energię w tej części Berlina, dającą impuls do licznych działań, wywołało obalenie w 1989 r. Muru Berlińskiego. Jawnej odnowie mogły ulec wartości wcześniej spychane przez prorosyjskie władze na dalszy plan, wtedy też rozpoczęto snucie planów odbudowy Elisabethkirche. Zwrot ku zachodowi i towarzyszący mu optymizm oraz gotowość do podjęcia dyskusji na marginalizowane wcześniej tematy religijne i etniczne znalazły w tym przypadku namacalne rezultaty: mobilizacja i początki działań przy ruinie tej świątyni nieprzypadkowo zbiegły się w czasie z momentem odsłonięcia kopuł Neue Synagoge $[18]^{8}$.

\section{Ciągłość funkcji religijnej jako warunek zachowania kościoła. Problem autentyzmu opuszczanej przestrzeni sacrum.}

W przypadku opuszczonych zabytkowych kościołów ich kompletność, odnosząca się do utilitas, venustas i firmitas została naruszona. Świadectwem rozluźnienia opisywanej relacji jest także dopuszczenie do rewitalizacji obiektów, w których intensywność wykorzystywania dla potrzeb pierwotnej funkcji nie pozawala na utrzymanie obiektu w zadowalającym stanie. Ograniczone użytkowanie, podobnie jak ich opuszczenie, przyczynia się do wypierania obiektów ze świadomości społecznej. Im mniej osób użytkuje zabytek, tym

\footnotetext{
${ }^{7}$ Zdjęcie NS-Propaganda am Portikus der St. Elisabeth-Kirche [20].

${ }^{8}$ Neue Synagoge, została wzniesiona w latach 1856-1866 według projektu Eduard Knoblaucha i Friedricha August Stülera, przy Oranienburger Strasse. Częściowej rekonstrukcji podjęto się w celu stworzenia w synagodze centrum edukacji, o charakterze muzealnym oraz siedziby fundacji zajmującej się ożywianiem i dokumentowaniem kultury żydowskiej w Niemczech. Początki działań restauratorskich przy ruinie spalonej w czasie nocy kryształowej (9-10 listopad 1938), miały miejsce na przełomie lat 80 . i 90. Widocznym efektem zainteresowania obiektem była odbudowa i odsłonięcie w 1989 roku charakterystycznych pozłacanych kopuł wieńczących fasadę [14].
} 
mniejszej liczbie będzie na nim zależało. Dla ciągłości tradycji najlepiej aby użytkowanie było „osobiste, fizyczne i możliwie pełne, a nie wirtualne. Bierność nie służy zabytkom, gdyż wyłącza je z kręgu aktywnych komponentów środowiska przestrzennego" [23].

Zgodnie z tą myślą w wielu europejskich kościołach można już zamieszkać, zjeść kolację, kontemplować sztukę, kupić książkę, poddać się zabiegom odnowy biologicznej, potańczyć czy zaparkować rower $[24,25,26]$. Nie zawsze jednak takie przekształcenia, wypierające, najpewniej ostatecznie, pierwotną funkcję, są uznawane za uzasadnione i właściwe. Część z nich budzi kontrowersje. Problematykę desakralizacji przestrzeni porusza przecież prawo kanoniczne [27] nakazujące, aby przyszła funkcja nie prowokowała, szanując uświeconą przeszłość tego miejsca. Wielu badaczy, tak jak monachijski teolog Ludwig Mödl, apeluje o zaprzestanie tego procesu: „zmniejszanie się liczby wiernych nie musi wiązać się z desakralizacją kościołów”, posiłkuje się argumentem, że „,...) ogromne kościoły klasztorne nie zostały wzniesione ze względu na liczebność mnichów, w większym stopniu miały wskazywać na sakralny wymiar i rangę budowli” [28]. W tej perspektywie większym zagrożeniem dla wielowiekowego dziedzictwa europejskiego, związanym z procesem laicyzacji, jest zaprzestanie praktyk religijnych rozumianych jako tradycja niematerialna scalająca społeczeństwo [29]. „To ogromna strata kulturowa dla Niemiec, która, najwidoczniej jeszcze nie zrozumiała tego opinia publiczna”, twierdzi historyk architektury Wolfgang Pehnt [28,27]. W tej perspektywie aktywność religijna uznana jest nie tylko za warunek trwania przestrzeni sakralnej, ale i zachowania dawnej spójności urbanistycznej i społecznej. W pytaniach o zachowanie pustoszejących kościołów należy więc zdaniem części badaczy dbać nie tyle o ich trwanie, co o ich celebrowanie. Tak poszerzona perspektywa, w której nie materia, a duch jest najistotniejszy, może zarówno blokować zmiany, jak i wzbudzać bardziej złożony sposób myślenia o dziedzictwie architektury sakralnej. Wydaje się, że dla wspólnoty ewangelickiej przedmieścia Spandau pytanie o trwanie zabytkowych kościołów nigdy nie dotyczyło zmiany ich funkcji, tylko jej redefinicji lub uzupełnienia. To ciekawa postawa, w której dopuszczalne są modyfikacje, ale jedynie te mieszczące się w określonych ramach. Taka perspektywa jest jak się wydaje, odpowiednim międzypokoleniowym kompromisem umożliwiający zmianę bez niszczenia tego, co - szczególnie dla osób starszych - jest wartością budującą tożsamość [28].

\section{Odbudowa po religijnej ruinie - perspektywa przedmieścia Spandau}

Tak jak przedstawiono to $\mathrm{w}$ poprzednich akapitach odbudowa ruin przedmieścia Spandau nie wiązała się tylko z próbą nadania zniszczonym dziełom architektury fizycznej spójności. Nawarstwiły się problemy. Po pierwsze długo nie było finansów i woli politycznej, aby subwencjonować takie przedsięwzięcia, co zdegradowało więź mieszkańców i obiektów. Po drugie, ruiny kościoła i synagogi, stały się tematem tabu, gdyż odzwierciedlały to wszystko, z czym niemieckie społeczeństwo musiało się skonfrontować po wojennej zawierusze. Nie znajdowano także funkcjonalnego uzasadnienia dla rekonstrukcji, zauważając że bez funkcji obiekty te stałyby się jeszcze większym problemem ekonomicznym. Cztery świątynie - Sophienkirche, Zionskirche, Golgathakirche oraz St. JohannesEvangelist-Kirche - poddane niewielkim naprawom, którymi dysponowała wspólnota ewangelicka $\mathrm{w}$ tej dzielnicy $\mathrm{z}$ naddatkiem zaspokajały potrzeby rytualne ${ }^{9}$. Stąd jednym z głównych problemów ruin stał się brak możliwości wypełnienia ich aktywnością.

9 Podobnie liczebność wspólnoty żydowskiej z ekonomicznego punktu widzenia w żaden sposób nie uzasadniałaby odbudowy miejsca ich dawnych zgromadzeń. 
Długo poszukiwano modelu, który oddałby cześć dawnym użytkownikom i ich tradycji, ale też dał szansę na utrzymanie zabytków w sposób inny od tradycyjnego, wymagającego ciągłych subwencji. Zastanawiano się nad niezbędną redefinicją lub rozbudową programu, tak aby nie nastąpiła „przymusowa”, ekonomiczna desakralizacja żadnego z kościołów. Pomimo, że przez 50 lat nie wykonywano fizycznych działań, to w tym czasie dokonał się etap najistotniejszy - dyskusji, waloryzacji, kompromisów i interpretacji. W efekcie uznano, że największą wartością definiującą autentyzm zabytku jest ciągłość funkcji. Przyznano też, iż mniejsza, pozornie nieekonomiczna częstotliwość użytkowania przestrzeni sakralnej nie musi być powodem tej funkcji całkowitego wygaszenia. Problem potraktowano jako wyzwanie, a nie porażkę wspólnoty. Jest to także przykład działań, w ramach których ,pomaga się wiernym w odnalezieniu ładu poznawczego na poziomie emocjonalnym i etycznym, aby zrytualizować i opóźnić nieodzowny jak się wydaje proces desakralizacji” $[28]^{10}$.
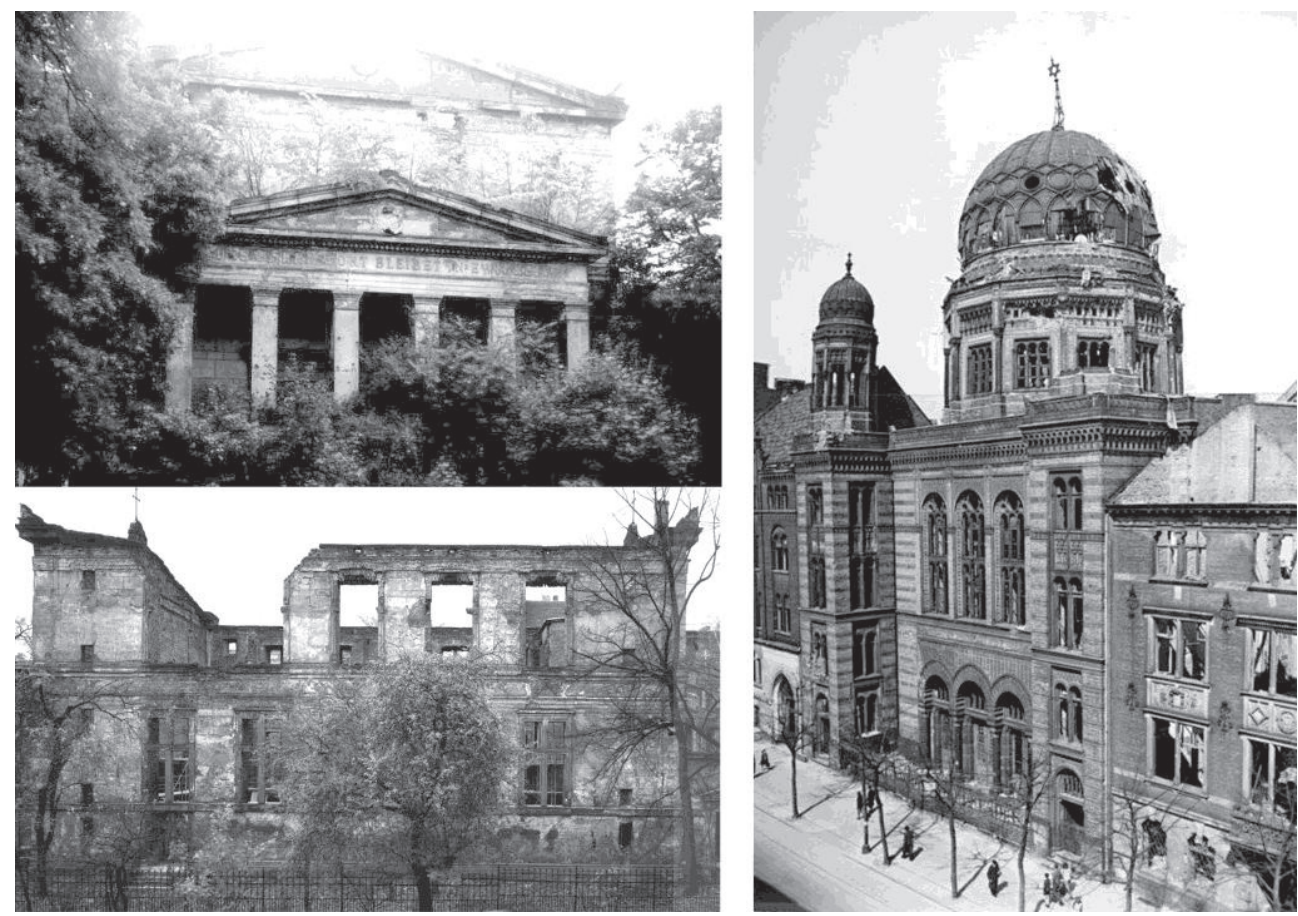

Rys. 3. Po lewej stronie- ruina kościoła St. Elisabeth (stan 1991, fot. Kultur Büro Elisabeth), po prawej stronie - zrujnowana w czasie „nocy kryształowej” Neue Synagoge. (fot. Centrum Judaicom)

\section{Idea, czas, współpraca}

Jak pokazują liczne zdjęcia St. Elisabeth z połowy 1991 roku [20] ${ }^{11}$ (rys. 3), zrujnowane dzieło K.F Schinkla nie było w żadnym stopniu objęte działaniami konserwatorskimi. W tym samym roku rozpoczęto oczyszczenie terenu oraz pierwsze niewielkie prace mające na celu zatrzymanie postępującej degradacji szczytu muru. W 1994 roku wykonano kon-

10 Clifford Geertz za Marta Kowalczyk [29].

11 Zdjęcia: St. Elisabeth, nach der Beräumung, 1946 oraz St. Elisabeth-Ruine, 1991. 
strukcję wsporczą dachu, stabilizując jednocześnie ściany obwodowe. Pierwszy etap nadzorowany przez właściciela obiektu, czyli biskupstwo ewangelickie, był niezbędny, ale jeszcze pozbawiony wizji przyszłego użytkowania. Duchowni potrafili odpowiedzieć na pytanie, w jakiej sytuacji się znajdują, i zdawali sobie sprawę z rangi obiektu, ale nie byli w stanie opisać realnego celu, do którego chcieliby tym przypadku dążyć.

Do właściwej adaptacji doszło na skutek synergetycznej współpracy organizacji religijnych i świeckich. W 1998 roku zawiązał się "Freundeskreis St. Elisabeth-Kirche, Berlin e.V.”. To stowarzyszenie wolontariuszy zafascynowanych historią tego miejsca stworzyło wizję przyszłego wykorzystania kościoła. Jest to o tyle istotne, iż energia i sposób myślenia tych osób o zabytku nie był obciążony stereotypami. Zauważyli oni, że w ciągu wieków kościół jako instytucja nieprzerwanie podejmował współpracę z artystami, a nawet stawał się ich mecenasem. Taka współpraca była zwykle korzystna dla obu stron: artysta miał fundusze, aby się rozwijać, Kościół zaś zyskiwał zarówno dobra materialne, jak i rozgłos niezbędny do stymulowania swojej pozycji polityczno-społecznej.

Choć trudno w obecnych czasach wygenerować takie środki, jakimi dysponowali znani biskupi i papieże to postanowiono uwspółcześnić i wykorzystać ten sam model. Głównym założeniem było aby pieniądze pochodzące $\mathrm{z}$ najmu przestrzeni sakralnych, miały dotować działalność artystyczną młodych twórców, którzy w zamian za to wspomogą proces ożywiania omawianych przestrzeni. Dopiero ta wizja koegzystencji sacrum i profanum pozwoliła ocalić integralności zabytku [31] ${ }^{12}$. Na skutek niemal dwuletnich rozmów z artystami, wolontariuszami, konserwatorami, wiernymi oraz mieszkańcami, zdecydowano, że odpowiednio nadzorowana funkcja artystyczna połączona z kontynuacją pierwotnej funkcji rytualnej jest idealną odpowiedzią na problemy tego miejsca. Efektem negocjacji stała się karta opisująca założenia, procedurę i kryteria oceny zgłaszanych projektów [32]. Jednym z głównych założeń jest konieczność podjęcia jakiejś formy dialogu z udostępnianą przestrzenią a także uszanowania jej sakralnej tożsamości.

Właściwie wszyscy byli zadowoleni z wypracowanego efektu. Artyści zyskali miejsce na ekspozycję, a biskupstwo zyskało werwę do działania i pomysł, który pomógł w jeszcze lepszym uzasadnieniu wydatków na rewitalizację ruiny. Automatycznie dotychczasowe budowlane działania konserwatorskie służące głównie zachowaniu autentycznej tkanki nabrały głębszego sensu, z zabezpieczenia ruiny prace przerodziły się w sensowną adaptację.

Idea "Freundeskreis St. Elisabeth-Kirche, Berlin e.V." ukształtowała funkcjonalne podstawy dla koncepcję adaptacji wykonanej przez biuro architektoniczne Klausa Blocka [33]. Filozoficzną podstawą dla adaptacji była chęć maksymalnego zachowania autentycznej tkanki, bez jej uzupełniania czy odtwarzania, a także wizualny minimalizm, który kontrastowałby z zachowaną malowniczością ruiny. Prace konserwatorskie i proces projektowy postępowały stopniowo. Dopiero po dziewięciu latach, w 2000 roku odnowiono portyk, wstawiono nową ślusarkę okienną oraz wykonano szklano-blaszane pokrycie dachu (rys. 4). Na tym etapie budynek nie nadawał się jeszcze do regularnego użytkowania, ale w celach promocji i oswojenia mieszkańców z nowym przedsięwzięciem, organizowano pojedyncze wydarzenia artystyczne i religijne.

W 2003 r. swoją działalność rozpoczęło Kultur Büro Sophien. Niewątpliwie obserwacja rewitalizacji kościoła St. Elisabeth przyczyniła się do powstania tego ewangelickiego stowarzyszenia stymulującego poza-religijne życie wspólnoty. Pierwotnie głównym jego celem była aktywizacja dzieci i młodzieży.

12 Autorka zwraca uwagę zarówno na rolę ekspertów jak i dialogu ze społeczeństwem. Zaznacza jednak, że opinia ekspertów powinna być tą bardziej znaczącą. 
W latach 2000-2008, w St. Elisabeth prowadzono kolejne drobne prace budowlane, jednak przebudowę wnętrza przeprowadzono dopiero w latach 2008-2009, po dokonaniu zmian prawnych ${ }^{13}$. Wykonano wtedy dwie klatki schodowe prowadzące na empory oraz niewielkie sanitariaty $\mathrm{w}$ przestrzeni pod pionami komunikacyjnymi (rys. 4). Budynek dostosowano do potrzeb osób niepełnosprawnych i dostaw, w tym celu wykonano przebicie we wschodniej elewacji kościoła (rys. 4). W 2014 roku na części ścian zamontowano okładziny akustyczne oraz wykonano stalowe klatki serwisowe. Do tej pory nie wykonano jeszcze wszystkich prac instalacyjnych. $Z$ tego powodu niektóre rozwiązania materiałowe, tak jak posadzka z kompozytowych płyt wiórowych, są tymczasowe. W przyszłości przewidziane jest wykonanie posadzki oraz ruchomych empor. Projekt Klausa Blocka nie obejmuje innych elementów, ale już otwarcie mówi się o kolejnych niezbędnych modyfikacjach. Użytkownicy marzą o podziemnej rozbudowie, która pozwoli na uzyskanie zaplecza scenicznego, magazynów oraz bloków sanitarnych [34].

Fundusze na remont płynęły z licznych źródeł. Artystyczna sława K.F. Schinkla, publiczno-prywatna formuła wspierająca kulturalne życie szerokiej grupy społecznej oraz lokalizacja na terenach dawnego Berlina Wschodniego niewątpliwie pomogły w rozpoczęciu rewitalizacji. W latach 1992-2000 fundusze pochodziły ze środków państwowych, środków z urzędu miasta, fundacji na rzecz ochrony niemieckiego dziedzictwa oraz funduszy wspólnoty kościoła ewangelickiego. W latach 2001-2009 prace rewitalizacyjne nie uzyskały już dofinansowania miasta, ale starania "Freundeskreis St. Elisabeth-Kirche" przyniosły efekt w postaci napływu pieniędzy od prywatnych fundatorów.

Prowadzone konsekwentnie i dwutorowo działania architektoniczne, społeczne i kulturalne wyzwoliły energię, która w 2014 r. roku zaowocowała zmianą struktury obu organizacji. W wyniku transformacji Kultur Büro Sophien i późniejszej rewitalizacji willi biskupiej przy St. Elisabeth wyłoniła się nowa organizacja: Kultur Büro Elisabeth. Rok 2014 to ważna data; moment, w którym wypracowano wieloaspektowy, zadowalający wszystkich kompromis. W samej nazwie zaakcentowano jednocześnie zmianę, w której kościół St. Elisabeth ponownie jest najbardziej zauważalnym i atrakcyjnym miejscem, wyróżniającym się na tle innych sakralnych obiektów przedmieścia. Adaptacja doprowadziła do rekonstrukcji zniszczonych przedwojennych relacji kulturowych i społecznych, a także przywrócenia utraconej hierarchii urbanistycznej i narracji, która niegdyś łączyła miejsca i ludzi. W ten sposób odbudowano zarówno „miasto rozumiane jako przestrzeń topograficzna, ale również miasto pojmowane jako relacja czasu [35]. To co może budzić wątpliwości w interpretacji tej adaptacji jako łącznika pomiędzy przeszłością a przyszłością tego miejsca, to niemożność wypełnienia luki po utraconych więzach religijnych, tak silnie cementujących społeczeństwo rytualnym uczęszczaniem na msze, gdyż obecne kulturowe interakcje animowane przez Kultur Büro Elisabeth są mniej regularne, dedykowane dla różnych odbiorców, fakultatywne a często także odpłatne. Tą wątpliwość w sposób matematyczny podważają wyniki badań zespołu Daniela Abramsa, w których nowoczesne laickie społeczeństwa mają liczne możliwości aby budować poczucie grupowej spójności, gdyż mogą integrować się w wielu alternatywnych miejscach: szkołach, miejscach pracy, miejscach rekreacji i rozrywki [3].

13 Organizacja i biskupstwo podpisali 10 letnią umowę najmu umożliwiającą przedłużenie jej na minimum 10 lat. Załącznikami do umowy były status organizacji, etyczne zasady funkcjonowania w strefie sacrum oraz forma nadzoru. 

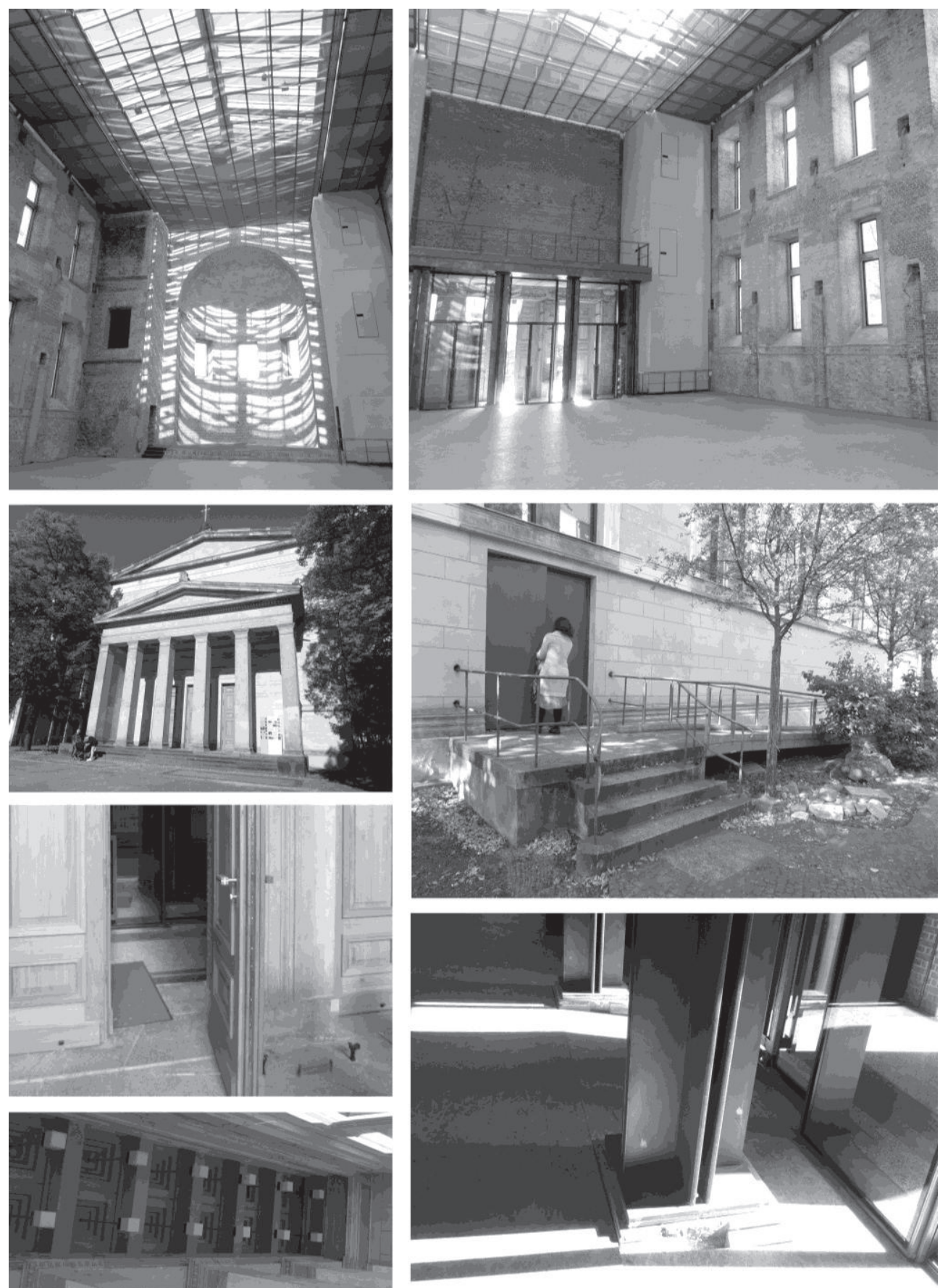

Rys. 4. Ruina St. Elisabeth po rewitalizacji. Prawa góra - widok wnętrza w stronę absydy, lewa góra widok na wejście, emporę i klatki schodowe, prawy środek - portyk po renowacji, lewy środek podjazd dla osób niepełnosprawnych, rampa dostawcza, prawy dół - detale portyku stolarka drzwiowa i oświetlenie, lewy dół - stalowe słupy oparte na zachowanej bazie podpory empory organowej (fot. Marta Rusnak) 


\section{Wystawy, koncerty, pokazy tańca i mody, konferencje i śluby}

Ze względu na brak ogrzewania większość wydarzeń w zaadaptowanej przestrzeni kościoła St. Elisabeth ma miejsce między kwietniem a wrześniem. Organizowane są tam między innymi: prelekcje, uroczystości o charakterze państwowym, spotkania ekumeniczne, warsztaty kulinarne i degustacje, szkolenia branżowe, aukcje, przedstawienia teatralne, wystawy, happeningi pozwalające na aktywne przebywanie w poreligijnym wnętrzu. Najczęstsze są jednak koncerty, nierzadko o charakterze charytatywnym. (rys. 5)

W celu organizacji konferencji najczęściej wynajmowany jest jednocześnie i kościół, i willa przy St. Elisabeth. Sama willa również często jest miejscem koncertów, pokazów tańca i instalacji artystycznych. Kolejną aktywizowaną przestrzenią jest skwer przylegający do willi i świątyni, gdzie co roku organizowane są festyny, w lecie zaś sprzedaje się zdrową żywność i prezentuje rękodzieło. Raz do roku urządzane są tam także nocne pokazy światła.

Niedogodnością, na którą najemcy kościoła i willi zwracają najczęściej uwagę, jest brak odpowiedniej liczby toalet; ten problem najczęściej rozwiązywany jest przy pomocy systemów mobilnych typu Toi Toi. Niekiedy niezadowolenie budzi także konieczność zakończenia wydarzenia przed godziną dwudziestą drugą. Ograniczenie to jest wynikiem interwencji mieszkańców pobliskich kamienic. W wyniku protestów i kilku interwencji policji, służby miejskie zleciły wykonanie badań akustycznych. Kształt przestrzeni powoduje, że nawet cicha rozmowa ponad trzech osób odbywana w pobliżu portyku generuje w nocy hałas przekraczający niemiecką normę. To ograniczenie zniechęca niektórych potencjalnych najemców.

Adaptacja Schinklowskiej ruiny i ożywienie wilii biskupów zwróciły uwagę na inne puste przestrzenie, którymi dysponuje społeczność ewangelicka. Jako możliwe do wykorzystania uznano także przestrzenie wszystkich kościołów, w czasie gdy nie odbywają się w nich nabożeństwa. W efekcie na zasadzie kolejnej ugody biura z biskupami zdecydowano się na komercyjne udostępnianie wszystkich świątyń. W tej grupie wyróżniono wnętrze kościoła St. Johannes-Evangelist. Jest to wyjątkowa pod względem architektonicznym przestrzeń właściwie w pełni oświetlona górnym światłem, co czyni z niej perfekcyjne narzędzie ekspozycji. Tak wiec od poniedziałku do piątku, a także w uzgodnione wcześniej soboty kościół może przerodzić się w salę konferencyjną, koncertową, galerię fotografii, a nawet miejscem uroczystej kolacji lub spotkań o charakterze politycznym.

W wyniku tych kompromisów działalność biura jest niezwykle dynamiczna. Patrząc na aspekty finansowe decyzja o powiększeniu zakresu działalności była trafna. Głównie dzięki temu posunięciu możliwe jest generowanie pieniędzy przeznaczane nie tylko na utrzymanie przestrzeni, ale także na remonty i finansowe wspieranie artystów. Opisana reorganizacja Kultur Büro Elisabeth umożliwiła zarejestrowanie jej w 2014 roku jako organizacji non-profit.

Najchętniej wynajmowanym miejscem jest właśnie St. Johannes-Evangelist, gdyż w przeciwieństwie do St. Elisabeth możliwe jest jego całoroczne użytkowanie. W kościele zorganizowano przykładowo: pokazy mody, liczne konferencję, wernisaże oraz przyjęcia weselne Odważono się również na zamontowanie we wnętrzu mobilnych ścianek wspinaczkowych. (rys. 6). Jako powód atrakcyjności tego kościoła najemcy podają głównie specyficzny klimat miejsca, łatwą dostępność oraz wykształcony w ciągu ostatnich lat prestiż. Najemcy podkreślają również to, co zauważa się wchodząc na stronę organizacji, czyli pełną, wręcz drobiazgową informację [34,36]. Stąd decydując się na najem wiedzą na przykład, że na zaproszeniu będą musieli poinformować gości o problemach z dostępnością dla osób niepełnosprawnych, oraz o braku publicznych ustępów. 

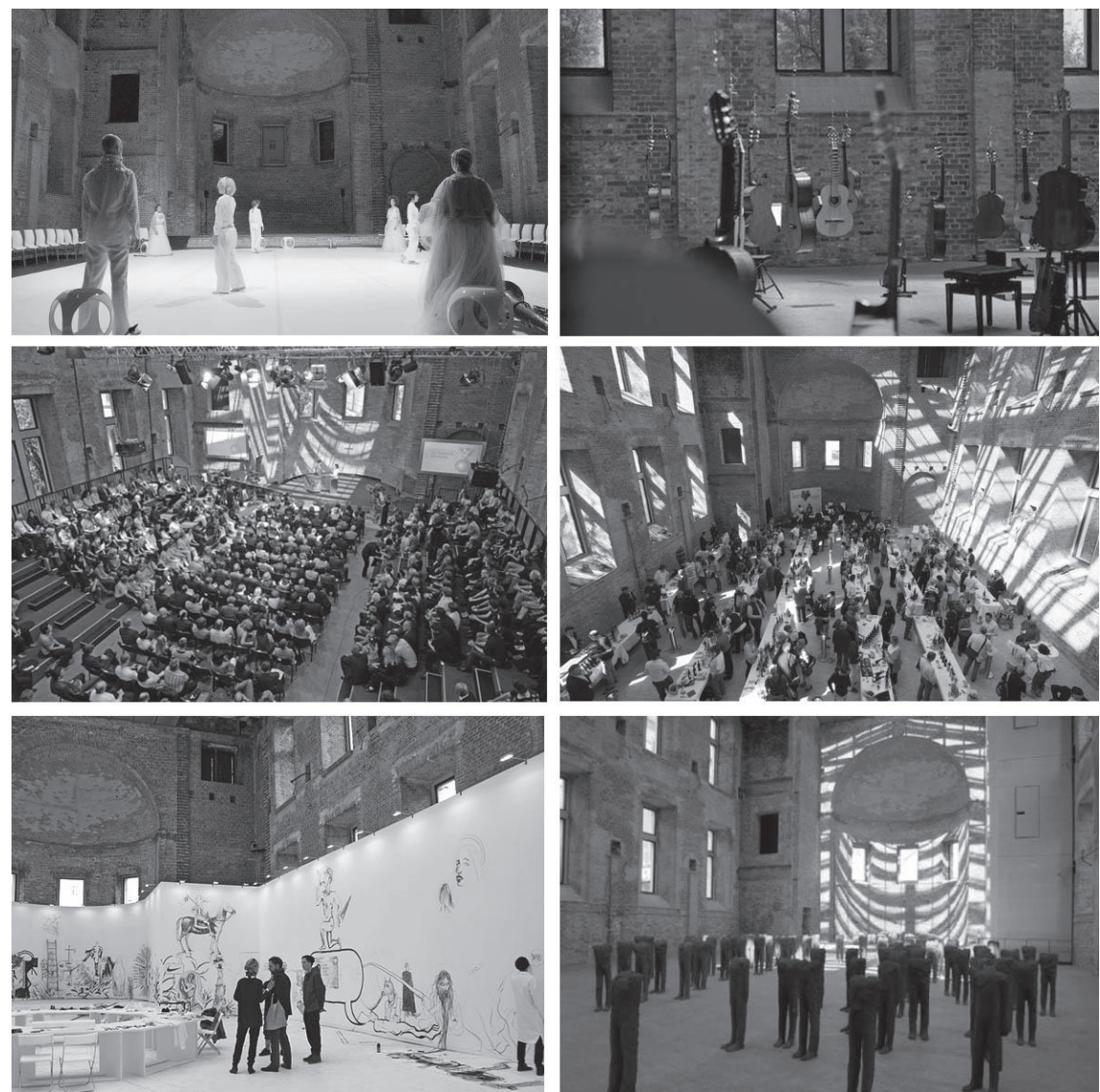

Rys. 5. Różne aranżacje i funkcje kościoła St. Elisabeth. (fot. Kultur Büro Elisabeth)
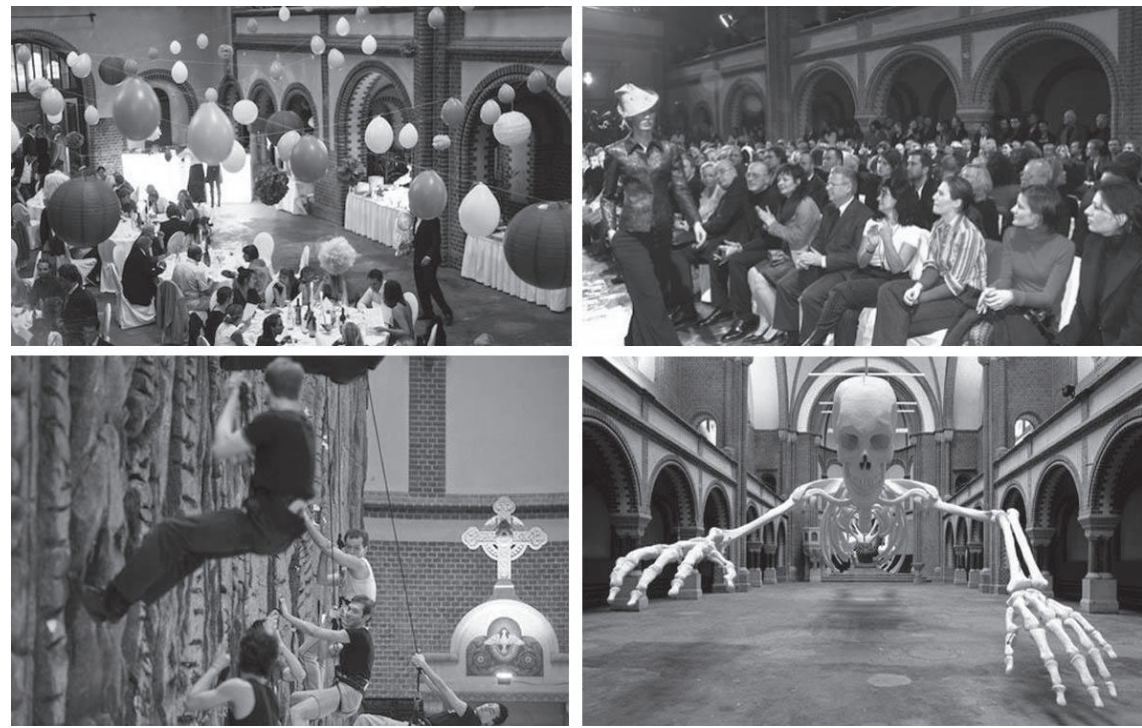

Rys. 6. Różne aranżacje i funkcje St. Johannes-Evangelist-Kirche. (fot. Kultur Büro Elisabeth) 
Umieszczane na stronie dane marketingowe są czytelne, a forma ich prezentacji niezwykle intuicyjna i komunikatywna. Zamiast słownego opisu konkretnych miejsc, foldery opatrzono licznymi zdjęciami i szkicami pokazującymi: położenie, relacje z otoczeniem a nawet przestrzenne możliwości aranżacji. Takie podejście uczciwie pokazuje ograniczenia, jednocześnie wydobywając pełnię komercyjnego potencjału każdego z tych miejsc. Właśnie w tym momencie najczytelniej widać interdyscyplinarne podejście osób które objęły opieką ten zabytek, bowiem każdy szczegół budujący relację tego zabytku ze współczesnością uznany został za niezwykle istotny. Stąd w zespole pracowników rolę koordynatorów pełnią kulturoznawcy i osoby po studiach z zakresu zarządzania kulturą.

Dominującą funkcją trzech opisanych powyżej przestrzeni - Elisabethkirche, willi biskupiej oraz kościoła St. Johannes-Evangelist-Kirche - jest funkcja kultury. W trzech pozostałych miejscach - Sophienkirche, Golgathakirche oraz Zionskirche - w dalszym ciągu przeważa funkcja religijna, choć jest regularnie urozmaicana poza religijnymi wydarzeniami. Przykładowo nawy boczne i empory Zionskirche cyklicznie zmieniają swój wizerunek poprzez aranżacje dla wystaw współczesnego malarstwa. W Sophienkirche poza organizacją prób i koncertów chórów, zdecydowano się na organizowanie wystaw na wcześniej nieużytkowanym, rozległym poddaszu. Dotychczas były to wystawy fotografii i instalacja wykonana ze starych instrumentów muzycznych. poddasze nie jest jednak idealnym miejscem ekspozycji ze względu na brak komfortu termicznego oraz ograniczenia dostępności związane z przepisami przeciwpożarowymi. Natomiast w lecie artystycznie ożywiany jest skwer przy tej świątyni. Najrzadziej użyczaną dla potrzeb pozarytualnych przestrzenią jest Golgathakirche. Najczęściej, ze względu na obecność organów, staje się on miejscem popisów wirtuozów tego instrumentu.

O synergicznej relacji pomiędzy strefami profanum i sacrum świadczyć może nie tylko różnorodna tematyka wystaw, koncertów i spektakli. O otwartym dialogu tradycji i popkultury wprowadzanej do wspólnoty ewangelickiej przedmieścia Spandau, mówią liczne, nietypowe z Polskiej perspektywy, wydarzenia. Przykładowo lektorzy w Zionskirche zainicjowali serię prelekcji dotyczących filmów, w których przedstawione są różne rodzaje duchowości lub mistycyzmu; jedna z prelekcji dotyczyła sagi Gwiezdne Wojny. W czasie spotkania można było wejść do Zinonskirche w przebraniu jednego z ulubionych bohaterów, z czego skorzystali nawet sami duchowni (rys. 7).
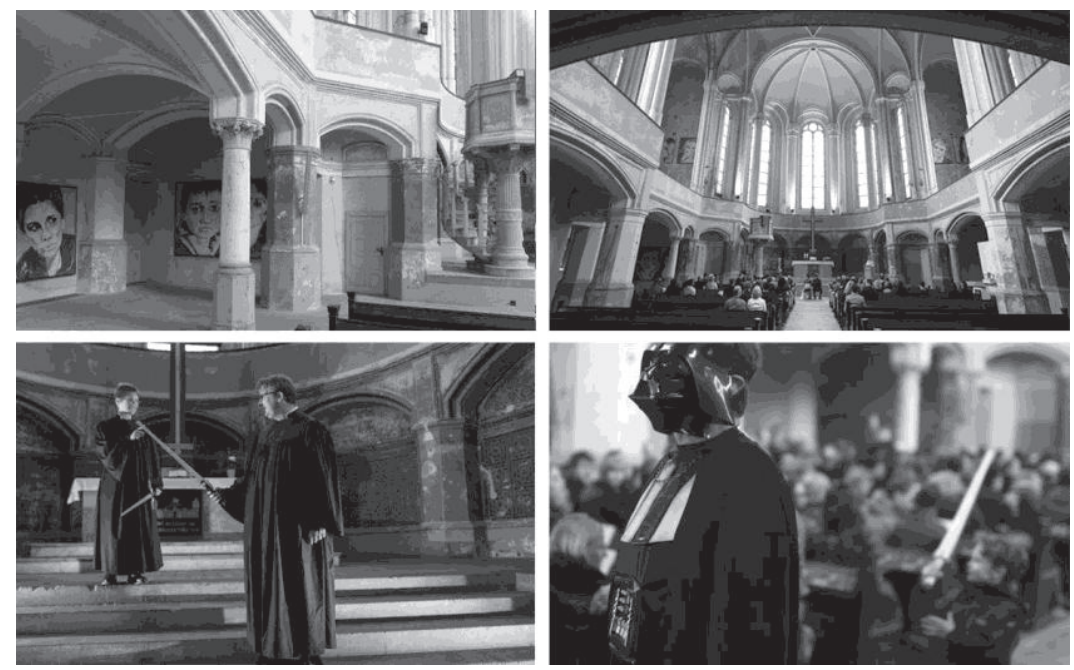

Rys. 7. Różne oblicza Zinonskirche (fot. Kultur Büro Elisabeth) 


\section{Podsumowanie}

Uzyskanie efektu synergii w czasie adaptacji zrujnowanego lub pustoszejącego zabytku sakralnego nie jest łatwe. Niewątpliwie, aby osiągnąć sukces, trzeba wykazać się wyobraźnią. Sam pomysł jednak nie wystarczy, aby poza chwilowym rozgłosem osiągnąć trwały efekt pobudzenia. Przede wszystkim proces rewitalizacji musi być wielowymiarowy, to znaczy, że musi uwzględniać wielorakie aspekty istnienia zabytku w odniesieniu do różnych skal badawczych. Stąd należy poznać historię i aktualną kondycję budynku, ale zawsze pogłębiając ją o jak najliczniejsze konteksty społeczne, polityczne, zarówno w skali ulicy, dzielnicy i miasta. Dopiero taka szeroka, interdyscyplinarna inwentaryzacja może na zasadzie porównania pokazać, co już utracono, jakie elementy z tej układanki są zagrożone zatarciem i jakie relacje jeszcze istnieją. Na takie studia należy poświęcić sporo czasu. Pośpiech może prowadzić do tworzenia złych hierarchii lub wyciągania nieprecyzyjnych wniosków. Istotne jest też, aby w czasie tej waloryzacji nie przekreślać elementów w jakiś sposób nieprzystających do stereotypowego postrzegania obiektu: smutnych, wstydliwych a nawet traumatycznych. One też stanowią wartość i mogą być istotnym elementem społecznej terapii, umożliwiającym zarówno inne spojrzenie na siebie jako członka grupy, jak i zaakceptowanie nowej funkcjonalnej wizji przekształcanego miejsca. Takie przyjmowanie dziedzictwa historii wydaje się o tyle trafne, że buduje ciągłość, która staje się zrytualizowanym [29] elementem przeżywania tego miejsca. Takie podejście pozwala także na odbudowanie relacji społecznych i religijnych w oparciu o zaufanie i prawdę. W St. Elisabeth dbałość o autentyzm materii i troska o autentyzm elementów pozamaterialnych stwarzają podstawę pod uzyskanie efektu synergii historycznego przekazu.

Innym niezbędnym aspektem synergii jest kompromis oparty na otwartej dyskusji. Wyłącznie to pozwala na osiągnięcie sukcesów organizacyjnych i ekonomicznych bez przedkładania ich ponad pierwotną tożsamość obiektu. Na takie porozumienie po raz kolejny należy poświęcić sporo czasu i wysiłku.

Aspekt czasu jest istotny również wtedy, gdy na proces rewitalizacji czy adaptacji patrzy się z perspektywy upływającego czasu - za sprawą bowiem upływu czasu taki proces może okazać się jednocześnie rytuałem swoistego przeniesienia budynku sakralnego do strefy profanum. Przebieg rewitalizacji może zagwarantować komfort poznawczy tym, którzy osobiście skonfrontują się z obcym im procesem laicyzacji i desakralizacji.

Zdaniem autorki, aby rewitalizacja zabytku była udana, a nawet stała się podstawą do kolejnych zmian, należy pozwolić, aby stała się ona także elementem rzeźby społecznej, w której każdy ma prawo do cząstkowego modelowania świata, w którym żyje. Wydaje się, że otwarta, prowadzona bez zbytniego pośpiechu i presji dyskusja pozwala każdemu z chętnych mieszkańców stać się ,,artystą" - współautorem wciąż transformowanego dzieła, jakim jest miasto oraz zanurzone $\mathrm{w}$ jego tkance zabytki. Pod względem materialnym adaptacja może mieć charakter rewolucji, jednak pod względem społecznym i urbanistycznym proces ten powinien być skoordynowany w harmonijnie ewoluującą całość.

\section{Literatura}

1. Słownik Języka Polskiego PWN,

http://sjp.pwn.pl/sjp/synergizm;2576856.htm dostęp 20.03.2016.

2. Krzemiński A. Czy Ratzinger przyspieszył laicyzację?, 5 marca 2013, Polityka Cyfrowa, [on line] http://www.polityka.pl/tygodnikpolityka/swiat/1536855,1,czy-ratzinger-przyspieszyllaicyzacje.read, (dostęp 21 stycznia 2016). 
3. Abrams D.M, Yaple H.A., Wiener R.J. A mathematical model of social group competition with application to the growth of religious non-affiliation. Phys. Rev. Lett. 107, 088701 (2011), [on line] http://arxiv.org/abs/1012.1375v1, dostęp 10.02.2016.

4. $\quad$ Raschke T. Die Sophienkirche in Berlin. s. 28.

5. Szambien W. Vorstadtkirchen. Karl Fridrich Shinkel, Basel, Boston, Berlin 1990, s.62.

6. Franz-Duhme H.N., Röper U. Shinkel Vorstadtkirchen. Kirchbau Und Gemeidegründung unter Fridrich Wilhelm III in Berlin. 1991 Berlin.

7. Steffens M., Schinkel K.F. An architekt In the service of beauty. Köln 2003, s. 69-71

8. von Lorck C., Schinkel K.F. Berlin 1939. s.72-73.

9. Architekturmuseum der TU Berlin, Sammlung Architektonischer Entrüfe, Elisabethkirche vor dem Rosenthaler Tor und Johanniskirche, Schinkel, Karl Friedrich; 1832, Inv: SAE:1858, 137.

10. Ort A., Zinons-Kirche in Berlin. w: Zeitschrift für Bauwesen, Berlin 1873, s.106-110.

11. Architekturmuseum der TU Berlin, Max Spitta, St. Johannes-Evagelist-Kirche, Inv. Nr. 16769, Inv. Nr. 16771.

12. N.N. Die Golgatha-Kirche in Berlin Berliner Architekturwelt 3 1901, s.349.

13. Architekturmuseum der TU Berlin, Max Spitta: Evangelische Golgathakirche, Berlin-Mitte, inv.nr. 16862.2., Inv.Nr.16863: Inv.Nr 16864.

14. udostępnione przez Kultur Büro Elisabeth, 03.09.2015.

15. Ausstellungstafel 175 Jahre St Elisabeth (Tafel 1) (Tafel 2), [on line] http:/www.elisabeth.berlin/kulturorte/st-elisabeth, dostęp 15 luty 2016.

16. Hundert Jahre St Elisabeth-Berlin: 1835-1935 ; Bilder aus d. Wachsen u. Werden e. evang. Kirchengemeinde d. Großstadt / Eugen Bethke. Hrsg. vom Gemeindekirchenrat v. St. Elisabeth, Berlin 1935.

17. Architekturmuseum der TU Berlin, Sammlung Architektonischer Entwürfe, Knoblauch, Carl Heinrich Eduard, Neue Synagogue, Inv. Nr. F 6897, Inv. Nr. F 6898, Inv. Nr. F 6900, Inv. Nr. EK 503,025, Inv. Nr. EK 503,0256, Inv. Nr. EK 503,037-043.

18. Simon H., Die Neue Synagoge, Berlin. Vergangenheit - Gegenwart - Zukunft. Berlin 1999.

19. Tołłoczko Z. ,, Sen architekta” czyli O historii i historyzmie architektury XIX i XX wieku. Kraków 2015, s.296.

20. Ausstellungstafel 175 Jahre St Elisabeth (Tafel 3) [online] http://www.elisabeth.berlin/kulturorte/st-elisabeth, dostęp 15.02.2016.

21. Obirek S., Pamięć Zagłady - brzemię i szansa. w: Obóz-muzeum, trauma we współczesnym wystawiennictwie, Kraków 2013, s13-30.

22. Wolf-Powęska A. Pamięć - brzemię i uwolnienie. Niemcy wobec nazistowskiej przeszłości (1945-2010). Poznań 2010.

23. Barełkowski R. Funkcja jako nośnik continuum w zabytku architektury. w: Wartość Funkcji w obiektach zabytkowych, Warszawa 2014, s.58-59.

24. Kb, Zamieszkać w domu Bożym, [online] <http://bryla.gazetadom.pl/bryla/1,85298,7493386, Zamieszkac_w_domu_Bozym.html>, dostęp 2010.02.08.

25. Kuśnierz-Krupa D., Krupa M. Nowe życie $w$ średniowiecznych kościołach $w$ Maastricht. Wiadomości Konserwatorskie, 24/2008, s.103-106.

26. Rusnak M. Transformation of religious buildings into museums in Poland: history and scale of the phenomenon. w: Architectus, 2015, nr 3, s. 75-88.

27. Kodeks prawa kanonicznego, Księga IV Uświęcone zadania Kościoła, Tytuł II Kościoły, kanon $1222, \S 1$.

28. Kościół w Niemczech, dlaczego jest tak źle? [online] http://www.pch24.pl/kosciol-wniemczech--dlaczego-jest-tak-zle-, 16727,i.html, dostęp 18.12.2016.

29. Aarticle 2, Definitions, Basic text of the 2003 Convention for the Safeguarding of the Intangible Curtural Heritage, UNESCO 2014 s.5 i ICOM (21 zgromadzenie Ogólne ICOM, Seul 2004.

30. Kowalczyk M., Desakralizacja kościołów. Rytuat sacrum czy profanum? w: Nurt SVD 2 (2011), rocznik 45, t. 130, Warszawa (Verbinum) 2011, s. 207-227.

31. Rouba B.J, Autentycznść i integralność zabytków. Ochrona zabytków, 4/2008, s.39.

32. pdf -Annahme von Kulturprojekten lub Selection of Cultural Projects, [online] http://www.elisabeth.berlin/kulturbuero/kultur-raum-geben (dostęp 3marca2016),

33. [online] http://www.klausblock.de/. 
34. Rozmówy z Teklą Wolf i Isabel Schubert - Gdańsk, 12-13 września 2014 oraz rozmową z Theklą Wolf- Berlin, 02-03.09.2015.

35. Riceur P. Pamięć, historia, zapomnienie. Kraków 2000, 195-196, za Grażyna Gajewska, Niewidzialne miasto-przypadek Gniezna, w: Muzeum XXI wieku. Teoria i praxis. Gniezno 2010, s.137-142,

36. Wywiady z najemcami (osobiste i mailowe) prowadzone od 06 do 10. $2015 \mathrm{r}$.

\title{
Kultur Büro Elisabeth in Berlin - Churches To Let
}

\author{
Marta Alina Rusnak \\ Department of History of Architecture, Art and Technique, \\ Wrocław University of Technology,e-mail: marta.rusnak@pwr.edu.pl
}

\begin{abstract}
After the end of World War II, Berlin - just like other parts of Germany and Europe - witnessed the phenomenon of growing secularization of society. In many regions the extent of this trend resulted in a dire need of ideas that would not only solve the problem of the shrinking budgets of religious communities, but also revive those buildings in possession of the Church that had become less and less often used. Forsaken temples equaled a decline in the town's coherence, since a part of what had been lost were the once significant social bonds that religious meetings had long helped keep alive. In Berlin, and in the Mitte district in particular, the issue of economic exploitation of religious objects gradually gained importance and the various ideas of what use to make of those buildings evolved over the course of nearly 50 years. Kultur Büro Elisabeth was formed in 2014 as a result of many transformations. It has been brought to life not only to save the world-class historical monument by K.F.Schinkel but also to restore past spatial and social relations. A dialogue that had carried out for years between the religious authorities, various experts, entrepreneurs and simple city dwellers made it possible to begin a multifaceted process thanks to which all the buildings of the Protestant Church in that part of Berlin are now given a new life - in terms of both their looks and use. Moreover, the buildings take part in creating modern cultural values, which contributes to the revival and/or reinterpretation of their past character. What is important, Kultur Büro Elisabeth has operated as a non-profit institution without funding from the authorities since 2014. This suggests that a model of operation has been worked out that is satisfactory from the economic perspective, too. Therefore it appears beneficial to take a closer look at the mechanism applied in Berlin and consider its possible adaptation in Poland.
\end{abstract}

Keywords: churches, revitalization, cultural adaptation, ruin, monument management, Berlin. 